DOI 10.31558/2519-2949.2021.3.8

УДК 929:321.01Драгоманов М.

ORCID ID: https://orcid.org/0000-0003-1042-4539

Олещук П. М., Київський національний університет імені Тараса Шевченка

ORCID ID: https://orcid.org/0000-0002-1522-4723

Салтовський О. І., Київський національний університет імені Тараса

Шевченка

\title{
СПІВВІДНОШЕННЯ ДЕРЖАВИ І АНАРХІЗМУ В ТЕОРЕТИКО-ПОЛІТИЧНІЙ СПАДЩИНІ МИХАЙЛА ДРАГОМАНОВА
}

Стаття присвячена аналізу особливостей трактування ролі держави у суспільному життя в політичній теорії видатного вченого і громадського діяча Михайла Драгоманова, чиї ідеї справили потужний вплив на політичний дискурс не лише в тогочасних Україні та Росії, але на всьому Європейському континенті. Для розкриття поставленої проблеми в даній розвідиі розглядаються питання трактування мислителем лібералізму як основи його соціально-політичної теорії, вплив на його погляди європейської прогресистської традииії. Розкривається також визначення вченим свободи індивіда як основного критерію суспільного прогресу та обмежувального впливу держави на їі реалізачію. Мислитель виходив з того, що, незважаючи на історично-прогресивний характер виникнення держави, воно, за своєю суттю, обмежує свободу індивіда, а за логікою розвитку, постійно прагне звузити межі иієї свободи. Звертається також увага на трактування М. Драгомановим проблеми формування умов для вільної самореалізаиії особистості. Державі мислитель протиставляє громаду, як добровільне об'єднання вільних людей, взаємовідносини між якими регулюються не методами примусу, а засобами морального регулювання. В статті наголошується на тому, що для українського теоретика політики федералізм $\epsilon$, пери за все способом організаиії взаємодії між суб'єктами політичного процесу. Зазначається, щчо анархістська риторика використовувалась М. Драгомановим не так з метою ліквідацї держави як такої, скільки для ії можливо більшого ослаблення на користь прав і свобод особистості. Вказується також на те, щзо на переконання вченого саме історія та сформовані основи національного характеру й політичних традицій визначають місие Украӥни і украйнців у загальнолюдському прогресі та переході людства від державної організації регулювання життя суспільства до його самоорганізаиії на засадах громадівського соиіалізму.

Ключові слова: М. Драгоманов, держава, громада, свобода, федералізм, анархізм, лібералізм.

Постать Михайла Драгоманова в українській політичній думці другої половини XIX сторіччя $€$ найбільш визначною. Саме він $\epsilon$, по суті, першим українським політологом, ідеї якого справили суттєвий вплив на європейський політичний дискурс кінця XIX-початку XX ст. Незважаючи на те, що його політичні твори написані у публіцистично-полемічній формі, вченому вдалось виробити досить послідовну і струнку політичну теорію.

«Думка Драгоманова синкретична. Вона поєднує демократичні, соціалістичні, патріотичні та космополітичні, слов'янофільські та західницькі елементи. Щоб охопити систему Драгоманова як органічну єдність, потрібно знайти центр тяжіння цього цілого. В його політичному мисленні такою центральною точкою і визначальним фактором $\epsilon$, без сумніву, ліберальна ідея» $[1$, с. 301].

Ліберальна ідея М. Драгоманова базується на його переконаності в тому, що основною одиницею суспільства є особа, добробут і щастя якої він вважає вищим критерієм розвитку людського суспыльства. Індивід, його невід'ємні права та життєві людські інтереси є тим «наріжним каменем» який вчений кладе в основу свого соціально-політичного вчення.

Аналізуючи історію розвитку людського суспільства, вчений приходить до висновку про те, що воля $є$ явищем стародавнім, а насильство, соціальне і національне пригноблення, тиранія виникають лише на певному етапі існування суспільства. Політична історія людства, вважає мислитель, $є$ колообігом трьох основних форм державного правління - аристократії, монархії та демократії. 


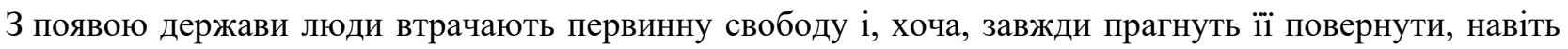
на певний час повертають, встановлюючи демократичні режими, однак, 3 конечною необхідністю, втрачають їі.

М. Драгоманов вважає, що причиною постійної втрати народом свободи є хибність її відновлення шляхом зміни форми державного правління. Держава за своєю суттю є інститутом, що протистоїть свободі індивіда, обмежує іiі i, за логікою свого існування, постійно прагне до обмеження прав і свобод особистості. Демократія закономірно вироджується в аристократію, аристократія в монархію і тиранію. І всі спроби змінювати суспільне життя шляхом реформування «зверху», через зміни форми державного правління, не можуть вирішити головної проблеми - повернути людям втрачену свободу.

Саме тому, замість ідеї «народоправства» вчений, як остаточний ідеал організації суспільного буття, висуває ідею «безначальства». «От дійти до того, щоб спілки людські, великі й малі, складались 3 таких вільних людей, котрі по волі сходились для спільної праці й помочі у вільні товариства, - це й єсть та ціль, до котрої добиваються люде, і котра зовсім не подібна до нинішніх держав. Ціль та зветься безначальство: своя воля кожному й вільне громадство й товариство людей і товариств» [2, с. 115].

В цілому соціально-політичний ідеал М. Драгоманова традиційно характеризують як анархістський, звертаючи увагу на його принципово негативне ставлення до держави як такої. Однак позначити вченого як «анархіста» зовсім не значить розкрити сутність його політичної концепції. Як відзначає Я.Довбищенко «Соціалістичним ідеалом Драгоманова був ідеал Прудона: федерація вільних спілок вільних людей. Ідеал, який повну волю людині і громаді клав в основу ідейної організації будучого суспільства. Отже, Драгоманов почасти був анархістом, але і з анархізмом взагалі, в його сучасному розумінню, теж не мав нічого спільного і до таких теоретиків і практиків анархізму, як Бакунін, Моста та Кропоткин ставився цілком негативно. Зовсім відкидав їхній аполітизм, їхню науку про державу та погляди на те, як дійти до здійснення соціялістичного ідеалу. Так само не любив і одхрещувався Драгоманів і од марксизму, котрий здавався йому занадто доктринерським («німецька метафізика»)» [3, с. 35].

Нерозуміння ідеологами анархізму, особливо російського, історичної необхідності держави було, на думку М. Драгоманова, їхньою головною помилкою, що заводила цей рух у глухий кут. Сам вчений вважав, що їх «... основна помилка, нерозуміння того, що держава і державні уряди $€$ формами і органами, котрі виробляються в народному житті (по волі, по неволі, як трапиться) і змінюються 3 ним, і що без цих форм і органів, тобто і без політики не може жити ніякий народ, ніяка людська громада. Найменше можуть обійтись без політики ті, хто скривджені в теперішніх державах, хто хоче чогось нового ... В XIX ст. ніякий громадський рух, в тому числі і національний, не обходиться без політики, без того, щоб примусити державні уряди перемінити чи встановити які державні закони...» [4, с. 390-391].

Для М. Драгоманова ліквідація держави, як механізму обмеження свободи особистості, не $\epsilon$ самоціллю. Він вважав, що завданням будь якого прогресивного політичного діяча, що щиро прагне до свободи народу є боротьба за вплив на державу, за те, щоб з допомогою держави, яку необхідно відповідним чином реорганізувати, добитись мінімізації ії ролі в суспільному життя та максималізації свободи особистості. Говорячи про позицію справжнього громадівця, він відзначає, що «В самих менших змінах, в змінах державних, він буде байдужий до того, як там впорядковується вище державне начальство, а більше наполягатиме на те, щоб вбільшити власне волю кожної особи в слові й праці, волю кожної людської породи, спілки, громади, країни, - щоб, скільки мога вменшити силу державного начальства, чи то царського, чи гетьманського, чи то управи (адміністрації), чи самої виборної ради (парляменту), перед силою особи, громади, і щоб дати їм більше способу до того, щоб зложити нові початки порядків безначальних: безпанських і бездержавних» [5, с. 120].

Позиція М. Драгоманова щодо держави та ії майбутнього, ролі, яку вона відіграє в своїй власній долі, значною мірою визначається тим, що його погляди формувались не лише під впливом ідей ідеологів російського революційного руху Чернишевського, Герцена, Михайловського, Лаврова, а й західноєвропейських - Прудона, Маркса, Енгельса, Лассаля. Однак найбільшою мірою визначальною була його філософсько-світоглядна позиція. «Ще в одній з молодечих праць (Римская исторія и Тацит) Драгоманов заявив себе позитивістом, ставши на цей грунт в 60-х роках, ще коли позитивізм Конта і Д.С.Мілля ледве став відомий в наукових колах» [6, с. 34]. Ідеї Конта, Спенсера, Мілля були найбільш співзвучними прагненням М. Драгоманова і саме їх, в першу чергу, він намагався донести до своїх земляків. 
М. Драгоманов був, як політичний діяч і теоретик, людиною доволі прагматичною. Він завжди був готовий відкинути те, що було не лише помилковим, але й не могло принести очевидної і відчутної користі в реалізації задуманої справи. При цьому мислитель досить послідовно дотримувався стратегічної мети, а компроміси вважав допустимими лише щодо тактики іiї реалізації. А.Круглашов підкреслює цю особливість і зазначає, що «... Драгоманова вигідно відрізняє те, що він намагався не відкладати реалізацію своїх політичних проектів «на потім», у невідоме «колись». Прагнення до практичних, відчутних результатів, його прагматизм, котрий критично чи 3 повагою відзначають дослідники, і становить особливість драгомановського теоретичного аналізу політичної дійсності, його виразну рису як теоретика і ідеолога» [7, с. 13].

М. Драгоманов обгруновував свій політичний прагматизм посилаючись на результати власних досліджень людської історії та розвитку наукового знання: «Те, що ми бачили досі в життю людському й що бачимо й тепер, показує, що життя те переміняється усякими способами й волею не одного гурту, і що не один гурт не може завше вживати безперемінно одних способів. Мало того, стан громади, серед котрої живе чоловік, в іншу хвилю збуджує такий дух, попихає громаду до таких способів, котрі перед тим і вгадати не можна. Ясно, що діло не в способах, а цілі, та в живій спільності чоловіка, котрий має думки про потребу зміни в порядках громадських, з тією громадою, серед котрої він живе» [2, с. 127].

Позитивістська філософія, що мала великий вплив на політичні погляди М. Драгоманова, значною мірою зумовлювала і систему пріоритетів його політичної діяльності та теоретичних шукань. На думку М.Шаповала вчений своїм першочерговим завданням ставив створення такої програми дій, виконання якої забезпечило б реалізацію ідеалу організації суспільного буття - безначальства. «Перш за все, за Драгомановим, у громадському процесі, як і в природньому, є свої закономірности для змін, ігнорувати ці закономірности не може той, хто хоче йти певно і твердо до мети. Для змін треба мати плян, виготовлений на засадах чистої (досвідної) науки» [6, с. 48].

Розробку цього плану М. Драгоманов вважав своїм призначенням, своєю особистою історичною місією. Це суттєвим чином зумовило не лише його погляди та практичну діяльність, але й ставлення до сучасників та їх ідей і програм. Врахування цього дозволяє пояснити багато фактів з життя мислителя. На цю особливість одного з провідним мотивів дій та теоретичних висновків вченого звертає увагу А.Круглашов: «Практична діяльність Драгоманова невіддільна від його намагань дати співвітчизникам, сучасникам таку програму політичної праці, котра враховувала би досвід минулого, відповідала потребам сучасності та брала до уваги можливості майбутнього. Це була більш ніж амбіція, це було глибоке переконання у своєму покликанні знайти відповіді на важливі запити суспільства, нації цивілізації. Таке «інтелектуальне місіонерство», що відчутно позначилось на самооцінках Драгоманова, на його вимогах до своєї праці в останні роки життя не могло не впливати на якість і зміст драгоманівських політичних поглядів» [7, с. 8].

М. Драгоманов не обмежував свої теоретичні шукання і політичну діяльність ні Україною, ні Російською імперією. Його думка охоплювала історичний процес всієї Європи і світу в цілому. Україна ж, в силу особливостей своєї історії, сформованої ментальності її народу, була лише однією 3 найбільш зручних територій для реалізації того, що він вважав метою світової історії - звільнення людини і людства.

В роботі «Переднє слово до «Громади»», що була своєрідною програмою діяльності так званого «женевського гуртка», зазначалось щодо співвідношення українських національних задач та загальнолюдських: «Ми ж думаємо, що усяка громадська праця на Україні повинна мати українську одежу, - українство. Звісно, те «українство» не може бути в цілях праці. Цілі праці людської однакові, як однакова здумана наука, Але прикладна наука не однакова скрізь. Так і з громадською працею: в кожній країні, в кожній людській породі, далі, навіть, в кожній громаді і коло кожної особи, - мусять бути осібні підходи й приводи до однакової цілі; кожна країна і купа людська може показати більш ясно, ніж другі, потребу і спосіб тієї чи іншої з тих праць, з того чи іншого способу праці, потрібної для всіх людей» [2, с. 122].

На думку вченого, стратегічна мета розвитку людства - забезпечення якнайкращих умов для вільної самореалізації особистості, та шляхи ії здійснення випливають з тези про те, що всі люди від природи прагнуть не лише до задоволення своїх особистих потреб та інтересів, а й до спілкування та об'єднання, де ці інтереси лише і можуть бути реалізованими. Основними формами таких об'єднань, які не порушують суверенітету особистості та забезпечують взаємодію між людьми, є громада і товариство. Вони протистоять державі, як добровільні форми об'єднання, насильницькій.

Громада, на думку М. Драгоманова, це не просто добровільне об'єднання людей, вона мусить бути об'єднанням вільних людей. Головною відмінністю громади від держави є те, що вона добровільно об'єднує вільних індивідів, а взаємовідносини між ними регулюються переважно 
засобами морального впливу. Громада не може нав'язати свою волю будь-кому з своїх членів силою, оскільки він має право в будь-який момент залишити іiі. Лише переконання, апеляція до розуму і совісті $є$ допустимими засобами нав'язування волі колективу одиниці. Громадський устрій, на думку вченого, $є$ найоптимальнішою формою поєднання особистих та групових інтересів, свободи індивіда та спільного обов'язку.

Драгоманівська думка йде від індивіда до об'єднання індивідів і далі, до створення національних та світової спілок добровільних об’єднань індивідів- громад. «Анархічні ідеали привели Драгоманова до федералізму. Це найвідоміша частина його політичної філософії. Кожен, хто взагалі чув про Драгоманова, знає, що він був федералістом. Вважають, що його метою була федералізація Росії, але насправді цей федералізм був універсальним принципом. Для політичного мислителя, який за свою вихідну точку бере незалежність особи і відкидає будь-яку форму авторитаризму, федерація прихильність рівноправн6их осіб до груп та громад і співпраця останніх у більших спілках - єдиний шлях подолати автономізацію суспільства» $[1$, с. 302$]$.

Федералізм у трактуванні М. Драгоманова виступає не тільки, i, навіть, не стільки формою територіального устрою, скільки головним способом взаємозв'язку суб'єктів політичної діїіндивідів, їх об'єднань, держави, міждержавних союзів і т.п. - сутність якого полягає в їх рівноправності. Лише рівноправні суб'єкти політичної взаємодії можуть так узгоджувати свої інтереси, щоб не порушувати прав і свобод один одного та уникати насильства.

«Федералізм мав для Драгоманова особливе значення, - більш глибоке, чим уявлення про майбутній, - близький чи далекий, - устрій Росії. Федералізм соціально-революційних російських організацій не перешкоджав їм бути найбільшими централістами в практично-організаційний діяльності, прихильниками диктатури партії або гуртка. У Драгоманова федералізм був системою не лише соціальною, але i політичною, і культурною,- навіть моральною... Федералізмом Драгоманова пронизано було його ставлення до партій, до людей, до способів і прийомів переконання супротивника. Цей федералізм був заснований на індивідуалізмі, на визнанні в кінцевому рахунку автономної особистості, права якої так само невід'ємні, як і право окремої громади. 3 цього федералізму випливала з необхідністю боротьба за політичну свободу» [8, с. 94].

Ідея федералізму не була чимось новим в українській політичній думці того часу. Ї̈ї витоки можна шукати вже в проектах утворення та реформування Козацької держави, в теоретичних побудовах учасників Кирило-Мефодіївського товариства. Особливу увагу їй приділяв М.Костомаров, вважаючи федеральну організацію держави історичною традицію українців. М. Драгоманов пізніше не раз публічно заявляв себе спадкоємцем ідей Кирило-Мефодіївського товариства 40-х рр., а одного 3 його головних ідеологів в «Листах на Наддніпрянську Україну»- M.І.Костомарова - називав своїм ідейним учителем щодо федералізму.

«Федералістичні погляди Драгоманова почали формуватись з 60-70-х pp. XIX ст. В 70-80-х pp. вони були викладені ним у ряді публіцистичних праць і склали певну систему його світогляду. У Драгоманова федералізм має два суспільно-історичні аспекти: федерація вільних громад (т. зв. громадівський соціалізм) i федерація автономних земств і країв як засіб буржуазнодемократичних перетворень» [9, с. 35].

Федералізм у трактуванні М. Драгоманова не є сталою, «завмерлою» ідеєю. Будучи прагматиком від політики, він постійно прагне наповнювати ії тим змістом, який в конкретний історичних умовах зможе забезпечити найбільш оптимальний шлях до реалізації головної мети - свободи особистості. Ліберально-демократична основа федералістичної концепції мислителя завжди лишилася незмінною. Змінювалась лише форма федералізму, якій він віддавав перевагу у той чи інший період своєї діяльності. В другій половині 70-х pp. XIX ст. він висунув програму безначальної спілки громад як кінцеву мету суспільних перетворень, що мали привести до побудови соціалістичного суспільства. Після спаду піднесення (розгром революційного народництва) і втратою надії на більш радикальні перетворення в Росії, вчений запропонував більш обмежену, і більш реальну, як йому здавалось, федералістичну програму, як найближчу мету - місцеву i крайову автономію при буржуазнодемократичних перетвореннях.

Однак у всіх випадках основу майбутньої федерації мали складати громади, спілки вільних людей, що добровільно вступали в певні політичні зносини для реалізації спільних інтересів. Спілки громад в подальшому об'єднувались в спілки спілок, а останні- в світову спілку, що була б покликана вирішувати питання глобального характеру. Такий шлях побудови всієї світової системи міжлюдських відносин - з низу до верху - був, на думку М. Драгоманова, єдино вірним і знімав небезпеку перетворення федерації на державу як засіб насильницького нав'язування волі одних іншим. I не лише меншості більшості, але й навпаки. 
Права і інтереси особистості для вченого завжди залишались вищою цінністю. Саме тому він неодноразово виступав проти ідеї «волі народу» якій мали бути підкорені особисті інтереси і воля окремих індивідів, та проти демократії, як системи в якій меншість повинна підкорятись більшості навіть в супереч своїм природним людським правам і інтересам.

Громадівство і федералізм, що базувалися на добровільності об'єднання та встановлюваних зв'язків між людьми в поєднанні з правом вільного виходу індивіда зі спілок, повинні були стати механізмами гарантування свободи особистості.

При цьому анархістська риторика, на думку ряду вчених, використовувалась М. Драгомановим не $з$ метою ліквідації держави як такої, а для її можливо більшого ослаблення на користь прав і свобод особистості. Так А.Круглашов вважає, що «У своїх програмних творах редактор і видавець «Громади» схилявся до федеративної, але держави, а не абстрактної федерації, що виступала замінником будьякої державності. I лише у своїх тлумаченнях засад майбутнього громадянського суспільства він справді охоче користувався анархістськими метафорами. Таким чином, анархістські концепції відчутно вплинули на критику Драгомановим недоліків державного устрою як у минулому, так і в його час. I, водночас, ці впливи залишили помітний слід там і тоді, де і коли Драгоманов намагався оцінити майбутню організацію суспільства саме як громадянського суспільства» [7, с. 417].

Перетворення царської Росії, Європи і всього світу на основі федералістичної ідеї, на думку М. Драгоманова, є тим засобом, який дозволить реалізувати головну мету всього суспільного розвитку. Адже людство в своєму розвитку все більше перетворюється з обособлених національних організмів на єдине ціле, в існуванні якого тільки й можна зрозуміти напрямок прогресу та його зміст. Для вченого спрямованість історичного процесу не викликає сумніву, головне - зрозуміти його напрямок і зосередити всі зусилля людства на реалізації головної мети його існування.

В роботі «Рай і поступ» М. Драгоманов зазначав, що «...коли дивитись на долю окремих народів, то можна часто не тільки не бачити поступу, але бачити навіть погіршення тієї долі, бо з часом траплялося, що цілі народи попадали в неволю до чужинців або й зовсім гинули. Але коли оглянути долю всіх народів на землі, принаймні з того часу з якого можна мати писемні спомини про ту долю, то безумовно завважаємо, що тим часом як в одного народу поступ часом інколи спинявся або й зовсім переривавсь, то він в другого народу все таки ішов далі, або що поступ з одного боку спинявся серед якогось народу, то з другого боку серед другого народу було якраз навпаки, аж поки згодом один народ - не навчався в другого тому в чому він остався позаду. Оглядаючи долю всіх народів, ми бачимо, що взагалі народи помалу зближаються між собою, виробляють з себе ніби одну громаду, передають один одному свої вигади й думки так, що з окремих народів виробляється дійсне людство, в котрому поступ не може перестати навіть в найгірші часи» [10, с. 65-66].

Українці, вважає вчений, також відіграють певну роль в загальнолюдському прогресі. Хоча в своїй історії Україна й знала періоди злетів і падінь, втратила державність, однак в умовах тогочасного світу вона має і ряд суттєвих переваг. Державність, на думку М. Драгоманова, для кожного народу дає суттєві переваги, головна з яких - можливість самостійно вирішувати власні проблеми. Однак сама по собі вона не дає простим людям суттєвих переваг в забезпеченні їх прав і свобод.

Головною особливістю сучасного йому етапу світової історії вчений вважає те, що «Тепер вже люде переросли державні спілки й прямують волею й неволею до якихось інчих. Тепер вже показалось, що і в тих породах людських, котрі мають свої держави й великі, багаті, й вільні (напр. як Франція, Англія), або й великі спілки вільних держав (як П. Американська Спілка) більша частина людей бідує мало чим менше, ніж бідують мужики українські» [2, с. 110-112].

Українці давно вже втратили державність, а разом з нею і експлуататорські класи, що робить їх надзвичайно сприятливими для ідей федералізму та громадівського соціалізму. «Ми думаємо, що наша Україна, котра немає ні свого попівства, ні панства, ні купецтва, ні держави, а має доволі розумне від природи мужицтво, - залюбки прийме науку про безначальні й товариські порядки, що через те на тій Україні, варто працювати громадівцям, а найбільш тим, котрі зросли в Україні» [2, с. 121].

Україна, таким чином, в силу історичних обставин, сформованої політичної традиції та особливостей національної ментальності $\epsilon$ найбільш близькою для реалізації громадівського суспільного ідеалу і покликана стати «локомотивом» європейського суспільного прогресу в напрямку розвитку до посилення в суспільному житті роботи принципів самоорганізації суспільного життя.

\section{Бібліографічний список:}

1. Лисяк-Рудницький I. Драгоманов як політичний теоретик // Лисяк-Рудницький І. Історичні есе. В 2 т. Т.1. / Пер. з англ. У.Гавришків, Я.Грицака. - К., 1994.

2. Драгоманов М.П. Переднє слово до «Громади» // Вибрані твори. Збірка політичних творів з примітками. - Прага-Нью-Йорк, 1937. - С.115. 
3. Довбищенко Я. Михайло Драгоманів. Його життя, наукова, політична та громадська діяльність // Пам’яти Михайла Драгоманова. - Харків, 1920.

4. Драгоманов М.П. «Сонячний промінь». Повість Василя Чайченка // Літературно-критичні праці: У 2 т. - К., 1970. - Т.2.

5. Драгоманов М.П. Переднє слово до «Громади» // Вибрані твори. Збірка політичних творів з примітками. - Прага-Нью-Йорк, 1937.

6. Шаповал М. Михайло Драгоманов, як ідеолог Нової України // Драгоманов М.П. Вибрані твори. Збірка політичних творів з примітками. - Прага-Нью-Йорк, 1937.

7. Круглашов А. Драма інтелектуала: політичні ідеї Михайла Драгоманова. - Чернівці, 2000.

8. Лисяк-Рудницький І. Драгоманов як політичний теоретик // Лисяк-Рудницький I. Історичні есе. В 2 т. Т.1. / Пер. з англ. У.Гавришків, Я.Грицака. - К., 1994.

9. Заславский Д. М.П.Драгоманов. Критико-биографический очерк. - К., 1924.

10. Іванченко Р.П. Михайло Драгоманов у суспільно-політичному русі Росії та України (II половина XIX в.). - K., 1971.

11. Драгоманов М. Рай і поступ. - Вінніпег, 1916.

\section{References:}

1. Ly`syak-Rudny`cz`ky`j I. Dragomanov yak polity`chny`j teorety`k // Ly`syak-Rudny`cz`ky`j I. Istory`chni ese. V 2 t. - T.1. / Per. z angl. U.Gavry`shkiv, Ya.Gry`czaka. - K., 1994.

2. Dragomanov M.P. Perednye slovo do «Gromady`»// Vy`brani tvory`. Zbirka polity`chny`x tvoriv z pry`mitkamy`. - Praga-N`yu-Jork, 1937. - S.115.

3. Dovby`shhenko Ya. My`xajlo Dragomaniv. Jogo zhy`ttya, naukova, polity`chna ta gromads`ka diyal`nist`// Pam’yaty`My`xajla Dragomanova. - Xarkiv, 1920.

4. Dragomanov M.P. «Sonyachny`j promin`». Povist`Vasy`lya Chajchenka // Literaturno-kry`ty`chni praci: U 2 t. - K., 1970. - T.2.

5. Dragomanov M.P. Perednye slovo do «Gromady`» // Vy`brani tvory`. Zbirka polity`chny`x tvoriv z pry`mitkamy`. - Praga-N`yu-Jork, 1937.

6. Shapoval M. My`xajlo Dragomanov, yak ideolog Novoyi Ukrayiny`// Dragomanov M.P. Vy`brani tvory`. Zbirka polity`chny`x tvoriv z pry`mitkamy`. - Praga-N`yu-Jork, 1937.

7. Kruglashov A. Drama intelektuala: polity`chni ideyi My`xajla Dragomanova. - Chernivci, 2000.

8. Ly`syak-Rudny`cz`ky`j I. Dragomanov yak polity`chny`j teorety`k // Ly`syak-Rudny`cz`ky`j I. Istory`chni ese. V 2 t. - T.1. / Per. z angl. U.Gavry`shkiv, Ya.Gry`czaka. - K., 1994.

9. Zaslavsky`j D. M.P.Dragomanov. Kry`ty`ko-by`ografy`chesky`j ocherk. - K., 1924.

10. Ivanchenko R.P. My`xajlo Dragomanov u suspil`no-polity`chnomu rusi Rosiyi ta Ukrayiny` (II polovy`na XIX v.). - K., 1971.

11. Dragomanov M. Raj i postup. - Vinnipeg, 1916.

\section{Oleshchuk P. M., Saltovskyi O. I. The Relationship between the State and Anarchism in the Theoretical and Political Heritage of Mykhailo Drahomanov}

The article is devoted to the analysis of the peculiarities of the interpretation of the role of the state in public life in the political theory of scientist and public figure Mikhail Drahomanov, whose ideas had a powerful influence on political discourse not only in Ukraine and Russia but throughout the European continent. Consideration of the interpretation of liberalism by Mykhailo Drahomanov as the basis of his socio-political theory and the impact on his views of the European progressive tradition address the main issues of this study. Scientist's definition of individual freedom as the main criterion of social progress and the restrictive influence of the state on its implementation is also revealed. Mykhailo Drahomanov proceeded from the fact that, despite the historically progressive nature of the state, it, in essence, restricts the freedom of the individual, and the logic of development, constantly seeks to narrow the boundaries of this freedom. Attention is also paid to M. Drahomanov's interpretation of the issue of creating conditions for free self-realization of the individual. The thinker opposes the community to the state as a voluntary association of free people, the relationship between which is regulated not by coercion but by means of moral regulation. The article emphasizes that for the Ukrainian political theorist, federalism is a way of organizing interaction between the subjects of the political process. It is noted that anarchist rhetoric was used by M. Drahomanov not so much to liquidate the state as such, but to weaken it as much as possible in favor of individual rights and freedoms. It is also specified that according to the scientist, history and the formed foundations of national character and political traditions determine the place of Ukraine and Ukrainians in universal progress and the transition of mankind from the state organization of society to its self-organization on the basis of socialism.

Keywords: M. Drahomanov, state, hromada, freedom, federalism, anarchism, liberalism. 